\title{
PENGEMBANGAN PERANGKAT PEMBELAJARAN COOPERATIVE TIPE GROUP INVESTIGATION UNTUK MENINGKATKAN MOTIVASI BERPRESTASI DAN KEMAMPUAN BERPIKIR KRITIS FISIKA PESERTA DIDIK
}

\author{
Yuli Astuti ${ }^{1)}$, Sutrio'), Ni Nyoman Sri Putu Verawati" ${ }^{1)}$ \\ 1)Program Studi Pendidikan Fisika, FKIP, Universitas Mataram, Mataram, NTB, Indonesia \\ Corresponding author : Yuli Astuti \\ E-mail : yuli69209@gmail.com
}

Diterima 11 Januari 2021, Direvisi 08 April 2021, Disetujui 14 April 2021

\begin{abstract}
ABSTRAK
Perangkat pembelajaran harus disertai dengan model pembelajaran yang sesuai dan yang paling memungkinkan untuk diterapkan dalam pembelajaran yang sesuai dengan kurikulum 2013 dan hakikat fisika sehingga pembelajaran menjadi bermakna. Penelitian ini bertujuan untuk mendeskripsikan validitas dan reliabilitas perangkat pembelajaran model cooperative tipe group investigation untuk meningkatkan motivasi berprestasi dan kemampuan berpikir kritis peserta didik. Jenis penelitian yang digunakan yaitu penelitian pengembangan (Research and Development) dengan model penelitian yang dikembangkan adalah 4D Models yang terdiri dari define, design, develop dan disseminate. Pengambilan data penelitian menggunakan lembar validasi yang dinilai oleh 6 validator ahli yang terdiri dari 3 orang dosen pendidikan fisika dan 3 orang guru mata pelajaran fisika. Data penelitian berupa data kualitatif dan kuantitatif dari penilaian validator terhadap perangkat pembelajaran yang dikembangkan. Perangkat pembelajaran tersebut meliputi silabus, RPP, LKPD, tes kemampuan berpikir kritis, dan angket motivasi berprestasi. Penelitian ini melakukan uji validitas untuk menentukan kelayakan dan tingkat validitas perangkat pembelajaran. Data hasil validitas diperoleh nilai rata-rata sebesar 3,33 berada pada kategori valid. Selanjutnya yaitu uji reliabilitas, diperoleh nilai rata-rata interval koefisien reliabilitas yaitu 0,850 dengan kategori sangat tinggi. Berdasarkan hasil tersebut, dapat disimpulkan bahwa perangkat pembelajaran model cooperative tipe group investigation untuk meningkatkan motivasi berprestasi dan kemampuan berpikir kritis fisika peserta didik valid dan reliabel digunakan dalam kegiatan pembelajaran.
\end{abstract}

Kata kunci: perangkat pembelajaran; cooperative tipe group investigation; kemampuan berpikir kritis; motivasi berprestasi.

\begin{abstract}
Learning devices must be in accordance with the appropriate learning model and the most possible to be applied in learning in accordance with the 2013 curriculum and the nature of physics so that learning becomes. This study aims to describe the validity and reliability of the cooperative learning model group investigation model to increase achievement motivation and thinking skills of students. The type of research used is research development (Research and Development) with the research model developed is the 4D Model which consists of define, design, develop, and disseminate. Retrieval of research data using validation sheets managed by 6 validator experts consisting of 3 physics education lecturers and 3 physics subject teachers. The research data is in the form of qualitative and quantitative data from the validator on the learning tools developed. These learning tools include syllabus, lesson plans, student worksheet, critical thinking skills tests, and achievement motivation. This study conducted a validity test to determine the feasibility and level of validity of the learning device. Data validity results obtained by an average value of 3.33 in the valid category. Furthermore, namely the reliability test, the average value of the reliability coefficient interval was 0.850 with the very high category. Based on these results, it can be seen that the cooperative learning model type of group investigation to increase achievement motivation and students' ability to think physics is valid and reliable used in learning activities.
\end{abstract}

Keywords: Development of learning tools; cooperative type group investigation; critical thinking ability; achievement motivation. 


\section{PENDAHULUAN}

Perkembangan ilmu pengetahuan dan teknologi yang begitu pesat merupakan ciri era globalisasi pada abad 21 sekarang ini. IImu pengetahuan serta teknologi pada abad ke-21 berkembang cukup pesat dan mempengaruhi segala bidang kehidupan terutama di bidang pendidikan. Menurut (Saavedra \& Opfer, 2012) terdapat lima keterampilan yang harus dimiliki oleh peserta didik pada abad ke-21 yaitu, kreativitas serta inovasi, berpikir kritis (critical thinking), pemecahan masalah (problem solving), pengambilan keputusan (decision making), dan metakognitif. Berdasarkan pendapat tersebut sangat penting bagi peserta didik untuk memiliki keterampilan abad ke-21.

Fisika sebagai salah satu bagian dari ilmu pengetahuan dan teknologi pada hakekatnya memiliki karakteristik sebagai proses, produk dan sikap. Fisika sebagai proses merupakan serangkaian proses ilmiah yang dilakukan dalam menemukan pengetahuan tentang fisika. Fisika sebagai produk berarti fisika dipandang sebagai kumpulan-kumpulan pengetahuan yang berupa fakta, konsep, generalisasi, prinsip, teori dan hukum fisika (Sari et al., 2016). Sementara fisika sebagai sikap artinya bahwa penyampaian pendapat serta ide-ide melalui sikap ilmiah dalam suatu proses fisika digunakan untuk menghasilkan produk fisika (Muammar et al., 2017), oleh karena itu, pembelajaran fisika tidak hanya menekankan pada aspek produk, tetapi tetap memperhatikan pada aspek proses dan sikap. Hakekat fisika yang demikian peserta didik dituntut melakukan suatu kegiatan ilmiah untuk menemukan pengetahuan dan memiliki sikap ilmiah agar dapat mengembangkan kemampuan berpikir kritis, menganalisis masalah dengan baik, berpikir secara sistematis dan cenderung untuk mencari kebenaran sebelum mengambil keputusan dalam pembelajaran (Handriani et al., 2015).

Pengembangan kemampuan berpikir kritis dalam pembelajaran dapat dipengaruhi oleh motivasi yang dimiliki peserta didik. Motivasi tumbuh di dalam diri peserta didik namun motivasi juga dapat dirangsang oleh faktor dari luar. Motivasi peserta didik yang rendah dapat berdampak pada proses dan hasil belajar yang tidak meningkat dengan baik atau bahkan dapat menurun (Ulya et al., 2016). Maka dalam upaya meningkatkan kemampuan berpikir kritis fisika peserta didik tersebut, faktor-faktor yang mempengaruhi kemampuan berpikir kritis fisika peserta didik perlu mendapat perhatian yang sungguh-sungguh.

Motivasi beprestasi sangat berperan penting dalam belajar. Dengan motivasi inilah peserta didik menjadi tekun dalam belajar dan dengan motivasi pula kualitas prestasi belajar peserta didik kemungkinan dapat diwujudkan dengan baik. Peserta didik yang dalam proses belajar mengajar mempunyai motivasi berprestasi yang kuat dan tekun kemungkinan besar memperoleh prestasi belajar yang memuaskan. Hal itu disebabkan oleh adanya ketiga fungsi motivasi yakni mendorong manusia untuk berbuat, jadi sebagai penggerak atau motor yang melepaskan energi. Motivasi dalam hal ini merupakan motor penggerak dalam setiap kegiatan yang akan dikerjakan. Kedua menentukan arah perbuatan, yakni kearah tujuan yang hendak dicapai. Dengan demikian motivasi dapat memberikan arah dan kegiatan yang harus dikerjakan sesuai dengan rumusan tujuannya, ketiga menyeleksi perbuatan, yakni menentukan perbuatan-perbuatan apa yang hendak dikerjakan yang serasi guna mencapai tujuan, dengan menyisihkan perbuatanperbuatan yang tidak bermanfaat tujuan tersebut (Arvyaty et al., 2016).

Berdasarkan hasil wawancara dengan 32 peserta didik kelas XI di SMAN 1 Gunungsari, fisika menjadi salah satu mata pelajaran yang sulit karena banyaknya persamaan yang di hafalkan. Kurangnya variasi pembelajaran menjadi alasan peserta didik kurang termotivasi dalam belajar dan berperan aktif dalam proses pembelajaran di kelas. Beranjak dari permasalahan tersebut, perlu adanya suatu upaya dan inovasi pembelajaran yang membantu peserta didik untuk membangun motivasinya sehingga akan lebih mudah untuk mengembangkan kemampuan berpikir kritisnya.

Salah satu upaya yang dapat dilakukan untuk melibatkan peserta didik secara aktif, menumbuhkan kemampuan berpikir kritis dan menciptakan lingkungan belajar menyenangkan yaitu dengan mengembangkan perangkat pembelajaran model kooperatif. Dalam pembelajaran kooperatif peserta didik dibentuk dalam kelompok-kelompok yang terdiri dari 4 sampai 5 orang dengan kemampuan akademik berbeda-beda yang melakukan kerjasama antar anggota kelompok sehingga mereka bertanggungjawab belajar untuk dirinya sendiri dan membantu sesama anggota kelompok untuk belajar (Daryanto \& Tasrial, 2014).

Berdasarkan permasalahan di atas dan juga hasil penelitian dari peneliti sebelumnya, peneliti tertarik untuk mengembangkan perangkat pembelajaran kooperatif tipe group investigation, dimana pembelajaran tipe group investigation ini menuntut peserta didik menemukan sendiri 
konsep-konsep materi yang dipelajari dengan cara investigasi sehingga diharapkan dapat mempengaruhi kemampuan berpikir kritis fisika peserta didik, hal ini menunjukkan bahwa dalam belajar fisika peserta didik tidak hanya menghafal rumus dan membaca buku teks melainkan peserta didik dituntut untuk berperan aktif secara langsung dalam kegiatan pembelajaran.

Pembelajaran fisika memberikan penekanan dan pendekatan proses untuk memperoleh produk, hal ini menunjukkan bahwa dalam pembelajaran fisika, peserta didik tidak hanya menghafal rumus, mendengar ceramah, dan membaca buku teks melainkan peserta didik dituntut untuk berperan aktif secara langsung dalam kegiatan belajar mengajar. Kemampuan berpikir kritis dapat di bangkitkan dengan memotivasi peserta didik dalam kegiatan pembelajaran, sehingga dengan memperhatikan motivasi yang dimiliki peserta didk maka diharapkan kemampuan berpikir kritis peserta didik dapat berkembang dengan baik.

Keberhasilan dalam proses pembelajaran sangat dipengaruhi oleh perangkat pembelajaran yang digunakan untuk itu perlu adanya pengembangan perangkat pembelajaran. Sebagaimana penelitian yang dilakukan oleh Putri (2017) berdasarkan hasil penelitian diketahui bahwa perangkat pembelajaran fisika berbasis keterampilan berpikir kritis dengan kriteria sangat valid. Transformasi pengembangan perangkat pembelajaran sangatlah perlu dan baik bagi peserta didik. Hal ini akan membuat keterampilan guru dalam mengajar meningkat dan kemampuan peserta didik meningkat, salah satunya yaitu kemampuan berpikir kritis. Perangkat pembelajaran yang akan dikembangkan yaitu perangkat pembelajaran berbasis model cooperative tipe group investigation. Bentuk perangkat pembelajaran yang dikembangkan masih sama dengan perangkat pembelajaran pada umumnya, namun dalam penelitian ini terdapat beberapa perbedaan yang menurut peneliti akan menjadi nilai kelebihan tersendiri. Pertama yaitu silabus, peneliti menyusun kegiatan pembelajaran yang mengarahkan peserta didik lebih berperan aktif dalan kegiatan pembelajaran. Kedua yaitu rencana pelaksanaan pembelajaran (RPP), peneliti mentranformasi sintak pembelajaran cooperative tipe group investigation di dalamnya. Ketiga yaitu LKPD, peneliti menyusun menyesuaikannya dengan sintak pembelajaran yang digunakan.

Kelebihan perangkat pembelajaran yang dikembangkan di atas maka proses pembelajaran akan tercipta kondisi student center, dikarenakan peserta didik lebih berperan aktif dalam memperoleh serta mengumpulkan informasi di kegiatan pembelajaran. Selanjutnya proses pembelajaran akan menuntun peserta didik terlatih dalam mengolah data berdasarkan informasi yang diperoleh untuk menjawab LKPD yang diberikan. Terakhir bahwa peserta didik mampu meningkatkan kemampuan berpikir kritis yang dimiliki, karena peserta didik dapat menganalisis pikirannya dalam menentukan pilihan dan menarik kesimpulan dengan cerdas (Yeritia et al., 2017). Berdasarkan pemaparan tersebut, perlu dilakukan penelitian lebih lanjut tentang "Pengembangan Perangkat Pembelajaran Cooperative Tipe Group Investigation untuk Meningkatkan Motivasi Berprestasi dan Kemampuan Berpikir Kritis Fisika Peserta Didik"

\section{METODE PENELITIAN Jenis penelitian}

Penelitian ini menggunakan metode penelitian dan pengembangan atau Research and Development $(\mathrm{RnD})$. Penelitian ini terdiri atas 4 tahap utama yaitu: (1) Define (pendefinisian); (2) Desain (perancangan); (3) Develop (pengembangan); dan (4) Desseminate (penyebarluasan). Masing-masing tahapan ini terdiri dari beberapa tahap. Tahap Pendefinisian (Define) terdiri dari analisis awal, analisis peserta didik, analisis tugas, analisis konsep, spesifikasi tujuan pembelajaran. Tahap perencanaan (design) merupakan tahap merancang draft awal perangkat pembelajaran yang akan digunakan dalam pembelajaran materi getaran harmonis. Silabus, RPP, LKPD, soal kemampuan berpikir kritis, dan angket motivasi berprestasi kemudian divalidasi oleh validator ahli. Tahap Pengembangan (Develop) terdiri dai penilaian validator ahli dan revisi produk. Sedangkan Tahap Penyebarluasan (Disseminate) merupakan tahap akhir dari tahap penelitian pengembangan ini. Pada tahap ini peneliti menyebarluaskan hasil penelitian dalam bentuk artikel ilmiah dipublikasikan secara online dalam jurnal ORBITA yang dikelola oleh UMMAT.

\section{Instrumen Penelitian}

Instrumen penelitian yang digunakan antara lain lembar validasi silabus, lembar validasi rencana pelaksanaan pembelajaran (RPP), lembar validasi lembar kerja peserta didik (LKPD), lembar validasi soal tes kemampuan berpikir kritis, dan lembar validasi angket motivasi berprestasi. Kemudian instrumen tersebut dinilai melalui angket validasi oleh 
validator untuk memperoleh data kuantitatif dan kualitatif penelitian.

\section{Teknik Pengumpulan Data}

Teknik pengumpulan data yang digunakan dalam penelitian ini yaitu angket validasi untuk validator. Teknik pengumpulan data dalam penelitian ini adalah memberikan lembar validasi kepada tim ahli dan guru untuk megetahui validitas silabus, RPP, LKPD, soal tes kemampuan berpikir kritis dan angket motivasi berprestasi.

\section{Teknik Analisis Data}

\section{Analisis Validitas Perangkat Pembelajaran}

a) Melakukan rekapitulasi hasil penilaian validator.

Mencari rerata setiap aspek dengan rumus :

Keterangan :

$$
\overline{A l}=\frac{\sum_{j=1}^{n} K_{i j}}{n}
$$

$\overline{A l}=$ rata-rata aspek ke-i

$K_{i j}=$ skor hasil penilaian terhadap kriteria ke-i oleh penilai ke-j

$n$ = banyak penilai

b) Mencari validitas penilaian validator untuk setiap aspek dan Mencari validitas dengan rumus :

$$
\bar{V}=\frac{\sum_{j=1}^{n} \overline{A_{l j}}}{n}
$$

Keterangan :

$V=$ Validitas

$A_{i j}=$ rata-rata nilai untuk aspek ke-i

$n$ = banyak aspek

Menentukan kategori validitas untuk setiap aspek dan keseluruhan aspek yang ditetapkan dengan menggunakan skala rating scale, data mentah yang diperoleh berupa angka kemudian ditafsirkan dalam pengertian kualitatif dilihat pada Tabel 1.

\begin{tabular}{cc}
\multicolumn{2}{c}{ Tabel 1. Kriteria Kevalidan } \\
\hline Nilai & Kriteria \\
\hline $3,5 \leq V \leq 4$ & Sangat valid \\
$2,5 \leq V \leq 3,5$ & Valid \\
$1,5 \leq V \leq 2,5$ & Cukup valid \\
$V \leq 1,5$ & Tidak valid \\
\hline & (Sugiyono, 2013).
\end{tabular}

Keterangan :

$\mathrm{V}=$ Validitas perangkat pembelajaran

\section{Analisis Reliabilitas Perangkat Pembelajaran} Reliabilitas dalam penelitian ini menggunakan metode Borich yang dikenal dengan Percentage Agreement (PA) yaitu persentase kesepakatan antar penilai yang merupakan suatu persentase kesesuaian nilai antara penilai pertama dengan penilai kedua. Instrumen dikatakan reliabel jika nilai presentase kesepakatannya lebih atau sama dengan 75\% (Borich, 1994).

Percentage Agreement (PA) dapat dirumuskan:

Keterangan:

$$
\mathrm{PA}=\left(1-\frac{\mathrm{A}-\mathrm{B}}{\mathrm{A}+\mathrm{B}}\right) 100 \%
$$

PA : Reliabilitas instrumen (percentage of agreetment)

A : skor penilai yang lebih besar

B : skor penilai yang lebih kecil

\section{HASIL DAN PEMBAHASAN \\ Hasil Penelitian}

Tahap pendefinisian (define) bertujuan untuk mendapat informasi mengenai keadaan peserta didik, permasalahan-permasalahan yang muncul ketka pembelajaran, metode pembelajaran yang digunakan oleh guru, media penunjang dan kajian kurikulum yang digunakan. Pada analisis awal, didapatkan informasi bahwa guru masih belum memperhatikan kemampuan berpikir kritis peserta didik. Hal ini terlihat dari pemilihan model pembelajaran yang dominan pengajaran langsung, serta penekanan fisika yang hanya memperhatikan persamaan matematis mengakibatkan peserta didik kurang aktif mengikuti kegiatan pembelajaran dan mengganggap fisika itu sulit. Pada analisis tugas, kurikulum yang digunakan adalah kurikulum 2013 pada KD 3.11 dan 4.11 yang kemudian ditentukan indikator ketercapaian kompetensi. Pada analisis konsep, materi yang digunakan yaitu Getaran Harmonis. Selanjutnya ditentukan spesifikasi tujuan pembelajaran.

$$
\text { Tahap perancangan (design) }
$$

merupakan tahap merancang draft awal perangkat pembelajaran yang akan digunakan dalam pembelajaran materi Getaran Harmonis. Draft yang dihasilkan berupa silabus, RPP, LKPD, soal tes kemampuan berpikir kritis dan angket motivasi berprestasi.

Tahap pengembangan (develop) merupakan tahap untuk menghasilkan produk pengembangan yang dilakukan melalui beberapa langkah, dalam hal ini yaitu penilaian validator ahli dan revisi produk. Berikut rangkuman hasil analisis validitas produk

\begin{tabular}{|c|c|c|c|}
\hline \multirow[t]{2}{*}{ No } & \multirow{2}{*}{$\begin{array}{c}\text { Perangkat } \\
\text { Pembelajaran }\end{array}$} & \multicolumn{2}{|c|}{ Validitas } \\
\hline & & Nilai & Kategori \\
\hline 1 & Silabus & 3,35 & Valid \\
\hline 2 & RPP & 3,40 & Valid \\
\hline 3 & LKPD & 3,13 & Valid \\
\hline
\end{tabular}
ditunjukkan pada Tabel 2.

Tabel 2.Rangkuman Hasil Analisis

ValiditasProduk oleh Validator Ahli 


\begin{tabular}{clcc}
4 & $\begin{array}{l}\text { Tes Kemampuan } \\
\text { Berpikir Kritis }\end{array}$ & 3,38 & Valid \\
5 & $\begin{array}{l}\text { Angket Motivasi } \\
\text { Berprestasi }\end{array}$ & 3,40 & Valid \\
\hline & Rata-rata & $\mathbf{3 , 3 3}$ & Valid \\
\hline
\end{tabular}

Reliabilitas dalam penelitian ini menggunakan metode Borich, yang dikenal dengan Percentage Agreement (PA) yaitu persentase kesepakatan antar penilai yang merupakan suatu persentase kesesuaian nilai antara penilai. Secara keseluruhan instrumen perangkat pembelajaran dikatakan baik apabila memiliki koefisien reliabilitas $\geq 75 \%$ atau $\geq$ 0,75 . Reliabilitas produk yang dikembangkan dapat dilihat pada tabel 3 .

Tabel 3. Rangkuman Hasil Analisis Reliabilitas Produk oleh Validator Ahli

\begin{tabular}{clcl}
\multicolumn{4}{c}{ Produk oleh Validator Ahli } \\
\hline No & $\begin{array}{c}\text { Perangkat } \\
\text { Pembelajaran }\end{array}$ & \multicolumn{2}{c}{ Reliabilitas } \\
\cline { 3 - 4 } 1 & Silabus & 0,883 & $\begin{array}{l}\text { Kategori } \\
\text { tinggi }\end{array}$ \\
2 & RPP & 0,912 & $\begin{array}{l}\text { Sangat } \\
\text { tinggi }\end{array}$ \\
2 & LKPD & 0,826 & $\begin{array}{l}\text { Sangat } \\
\text { tinggi }\end{array}$ \\
3 & Tes Kemampuan & 0,819 & $\begin{array}{l}\text { Sangat } \\
\text { tinggi }\end{array}$ \\
4 & Berpikir Kritis & Tinggi \\
5 & $\begin{array}{l}\text { Angket Motivasi } \\
\text { Berprestasi }\end{array}$ & 0,858 & Tangat \\
\hline \multirow{2}{*}{ Rata-rata } & $\mathbf{0 , 8 5}$ & $\begin{array}{l}\text { Sangi } \\
\text { tinggi }\end{array}$ \\
\hline
\end{tabular}

Setelah melalui tahap pengembangan, produk perangkat pembelajaran akan melalui tahap uji kelayakan. Tujuannya yaitu untuk melihat efisien, efektivitas maupun ketepatan dan kebenaran produk. Uji kelayakan disini peneliti menggunakan penilaian validator ahli, sehingga produk tidak melalui tahap uji coba. Hal ini atas pertimbangan kondisi saat penelitian yaitu situasi pandemi covid-19 serta keterbatasan waktu penelitin dalam menyelesaikan penelitian. Sehingga fokus utama untuk mencapai tujuan penelitian yaitu mencapai produk perangkat pembelajaran yang valid dan layak terdapat pada tahap uji kelayakan ini.

\section{Pembahasan}

Berdasarkan tabel-tabel hasil analisis data di atas terdapat beberapa poin pembahasan. Pertama silabus, silabus yang dihasilkan yaitu mengukuti format $\mathrm{K}-13$, kemudian pada bagian isi silabus ini memuat sumber belajar bervariasi serta kegiatan pembelajaran menyesuaikan dengan sintak model yang digunakan. Hal ini didukung oleh penelitian pengembangan yang dilakukan oleh (Putri \& Djamas, 2017) bahwa penelitian ini menghasilkan perangkat pembelajaran fisika berbasis keterampilan berpikir kritis dengan kriteria sangat valid.

Kedua yaitu RPP, RPP dihasilkan memiliki format yang sama dengan RPP pada umumnya, namun pada kegiatan inti mengikuti sintak model cooperative tipe group investigation. Sintak pada kegiatan inti terdapat 6 fase dengan penggunaan media powerpoint pada fase ke 1. Hal ini didukung oleh penelitian pengembangan yang dilakukan oleh (Yusuf, 2015) yang menyatakan bahwa terdapat perbedaan yang signifikan antara pengetahuan peserta didik sebelum dan sesudah diberikannya model pembelajaran cooperative tipe group investigation.

Ketiga yaitu LKPD, LKPD yang dikembangkan menyesuaikan dengan sintak RPP cooperative tipe group investigation sehingga pada fase ke 2 kegiatan inti LKPD digunakan. LKPD juga memuat identifikasi masalah dan pertanyaan yang akan dipecahkan oleh peserta didik yang mengarahkan peserta didik dapat mengembangkan kemampuan berpikir kritisnya. Hal ini didukung oleh penelitian yang dilakukan oleh (Fitriyah, 2016) menjelaskan bahwa perangkat pembelajaran dengan pendekatan scientific pada pembelajaran IPA valid dan reliabel digunakan untuk melatih kemampuan berpikir kritis peserta didik .

Keempat yaitu tes kemampuan berpikir kritis, yaitu berisi soal untuk mengukur tingkat kemampuan berpikir kritis fisika peserta didik yang didalamnya mencakup pertanyaan dengan tingkat taksonomi Bloom mulai C1 sampai C6, sehingga soal termuat berdasarkan indikator yang ada pada indikator kemampuan berpikir kritis yang dijabarkan oleh Ennis(2011). $\mathrm{Hal}$ ini didukung oleh penelitian yang dilakukan oleh (Kariawan, 2015) yang menyatakan bahwa perangkat pembelajaran fisika telah memenuhi kriteria valid untuk meningkatkan kemampuan berpikir kritis.

Selanjutnya yaitu angket motivasi berprestasi, yaitu berisi daftar pertanyaan tertulis yang digunakan untuk memperoleh keterangan tertentu dari responden yang kadang-kadang tersebar tempat tinggalnya. Hal ini didukung oleh penelitian yang dilakukan oleh (Utami, 2017) yang menyatakan bahwa hasil penilaian ahli materi untuk menguji kevalidan perangkat pembelajaran dinyatakan bahwa perangkat pembelajaran valid dan berkategori baik. Hasil uji coba menunjukkan bahwa produk yang dikembangkan valid serta memenuhi kriteria praktis dan efektif dalam meningkatkan motivasi berprestasi belajar peserta didik.

Terakhir yaitu berdasarkan rata-rata dari nilai validitas dan reliabilitas maka produk 
perangkat pembelajaran yang dihasilkan berada pada tingkat validitas $(3,33$ : valid) dan tingkat reliabilitas $(85,0 \%$ : sangat tinggi).

\section{SIMPULAN DAN SARAN}

Berdasarkan hasil penelitian dan pembahasan dapat disimpulkan bahwa perangkat pembelajaran model cooperative tipe group investigation untuk meningkatkan motivasi berprestasi dan kemampuan berpikir kritis fisika peserta didik valid dan reliabel digunakan dalam kegiatan pembelajaran.

Saran untuk penelitian selanjutnya yang sejenis agar penelitian ini dilakukan sampai uji coba skala luas. Penelitian pengembangan seperti ini dapat dilakukan pada konsep lain dengan cangkupan materi yang lebih luas dengan harapan mampu meningkatkan motivasi berprestasi dan kemampuan berpikir kritis fisika peserta didik.

\section{DAFTAR RUJUKAN}

Arvyaty, Faad M., \& Naimin Noho. (2016). Pengaruh Motivasi Berprestasi Terhadap Prestasi Belajar Matematika Siswa SMA Negeri dan SMA Swasta Di Kota Kendari. Jurnal Pendidikan Matematika 1( 7): 26-42.

Borich, G. D. (1994). Observation Skill for Effective Teaching. New York: Macmillan Publishing Company Daryanto., \& Tasrial. 2012. Konsep Pembelajaran Kreatif. Yogyakarta: Gava Media.

Daryanto., \& Tasrial. (2014). Konsep Pembelajaran Kreatif. Yogyakarta: Gava Media

Ennis, R.H. (2011). The Nature of Critical Thinking: An Outline of Critical Thinking Disposition and Abilities. University of Illinois. On line at http://faculty.education.illinois.edu/rhen nis/documents/TheNatureocCriticalThi nking 51711 000.pdf.

Fitriyah, K. (2016). Pengembangan Perangkat Pembelajaran Dengan Pendekatan Scientific Untuk Melatih Kemapuan Berpikir Kritis Siswa Pada Pembelajaran Ipa Materi Cahaya Kelas IV SD. Jurnal Review Pendidikan Dasar 3(2): 265-276.

Handriani, L.S., Harjono, A., \& Doyan A. (2015). Pengaruh Model Pembelajaran Inkuiri Terstruktur Dengan Pendekatan Saintifik Terhadap Kemampuan Berpikir Kritis Dan Hasil Belajar Fisika Peserta didik. Jurnal Pendidikan Fisika dan Teknologi. 1(3): 210-220.

Kariawan, I. G., Sadia, I. W., Pujani, N. M. (2015). Pengembangan Perangkat
Pembelajaran Fisika Dengan Setting Model Pembelajaran Inkuiri Untuk Meningkatkan Kemampuan Pemecahan Masalah Dan Kemampuan Berpikir Kritis Siswa SMA. Jurnal Program Pascasarjana Universitas Pendidikan Ganesha (5). 1-11.

Muammar, H., Harjono, A., \& Gunawan, G. (2017). Pengaruh Model Pembelajaran Assure dan Pengetahuan Awal Terhadap Hasil Belajar IPA-Fisika Peserta didik Kelas VIII SMPN 22 Mataram. Jurnal Pendidikan Fisika dan Teknologi. 1(3): 166-172.

Putri, S. R., \& Djamas, D. (2017). Pengembangan Perangkat Pembelajaran Fisika Berbasis Keterampilan Berpikir Kritis Dalam Problem-Based Learning. Jurnal Ilmiah Pendidikan Fisika Al-Biruni. 6(1): 125135.

Sari, P. I., Gunawan, G., \& Harjono, A. (2016). Penggunaan Discovery Learning Berbantuan Laboratorium Virtual pada Penguasaan Konsep Fisika Peserta didik. Jurnal Pendidikan Fisika dan Teknologi. 2(4): 176-182.

Saavedra, A., \& Opfer, V. (2012). Teaching and Learning 21st Century Skills: Lessons from the Learning Sciences. A Global Cities Education Network Report. New York, Asia Society.

Sugiyono. (2014). Metode Penelitian Kuantitatif Kualitatif dan R\&D. Bandung : Alfabeta.

Trianto, T. (2010). Mendesain Model Pembelajaran Inovatif-Progresif. Jakarta : Kencana Prenada Media Group.

Ulya, I.F., Irawati. R., \& Maulana. (2016). Peningkatan kemampuan koneksi matematis dan motivasi belajar peserta didik menggunakan pendekatan kontekstual. Jurnal Pena IImiah. 1(1). 121-130.

Utami, K., N., \& Mustadi, A. (2017). Pengembangan Perangkat Pembelajaran Tematik Dalam Peningkatan Karakter, Motivasi, Dan Prestasi Belajar Siswa Sekolah Dasar. Jurnal Pendidikan Karakter.1(1). 14-25.

Yeritia, S., Wahyudi., \& Rahayu, S. (2017). Pengaruh Model Pembelajaran Inkuiri Terbimbing Terhadap Penguasaan Konsep dan Kemampuan Berpikir Kritis Fisika Peserta Didik Kelas X Sman 1 Kuripan Tahun Ajaran 2017/2018. Jurrnal Pendidikan Fisika dan Teknologi. 3(2): 181-187.

Yusuf, M.Y. (2015). Pengembangan Perangkat Pembelajaran Menerapkan Model 
Pembelajaran Kooperatif Tipe Group Investigation ( $\mathrm{Gi}$ ) Berbantuan Software Isis Proteus Dan Codevisionavr Untuk Meningkatkan Hasil Belajar Siswa Pada Mata Pelajaran Teknik Mikroposessor. Jurnal Pendidikan Teknik Elektro 1 (4). 1-9. 